\title{
Tools for the Assessment of the Malnutrition Status and Possible Interventions in Elderly with Cardiovascular Diseases
}

\author{
Elisabetta Tonet ${ }^{1, *}$, Roberta Campana ${ }^{1}$, Serena Caglioni ${ }^{1}$, Federico Gibiino ${ }^{1}$, Alessio Fiorio ${ }^{1}{ }^{1}$, \\ Giorgio Chiaranda ${ }^{2}$, Silvia Zagnoni ${ }^{3}$, Gianni Casella ${ }^{3}$ and Gianluca Campo ${ }^{1}$ (i) \\ 1 Cardiovascular Institute, Azienda Ospedaliero-Universitaria di Ferrara, 44124 Cona, Italy; \\ robertacampana22@gmail.com (R.C.); s.caglioni@studenti.uniba.it (S.C.); federico.gibiino@hotmail.it (F.G.); \\ alessiofiorio@virgilio.it (A.F.); cmpglc@unife.it (G.C.) \\ 2 Department of Public Health, AUSL Piacenza, and Sport Medicine Service, 29121 Piacenza, Italy; \\ g.chiaranda@ausl.pc.it \\ 3 Department of Cardiology, Ospedale Maggiore, 40133 Bologna, Italy; zagnonis@gmail.com (S.Z.); \\ gianni.casella@ausl.bologna.it (G.C.) \\ * Correspondence: tonet.elisabetta@gmail.com; Tel.: +3-905-3223-7227; Fax: +3-905-3223-9531
}

check for

updates

Citation: Tonet, E.; Campana, R.; Caglioni, S.; Gibiino, F.; Fiorio, A.; Chiaranda, G.; Zagnoni, S.; Casella,

G.; Campo, G. Tools for the

Assessment of the Malnutrition Status and Possible Interventions in Elderly with Cardiovascular Diseases. J. Clin. Med. 2021, 10, 1508. https:// doi.org/10.3390/jcm10071508

Academic Editor: Simone Biscaglia

Received: 1 March 2021

Accepted: 1 April 2021

Published: 4 April 2021

Publisher's Note: MDPI stays neutral with regard to jurisdictional claims in published maps and institutional affiliations.

Copyright: (c) 2021 by the authors. Licensee MDPI, Basel, Switzerland. This article is an open access article distributed under the terms and conditions of the Creative Commons Attribution (CC BY) license (https:/ / creativecommons.org/licenses/by/ $4.0 /)$.

\begin{abstract}
Malnutrition represents a common and important feature in elderly people affected by cardiovascular diseases. Several studies have investigated its prevalence and prognostic role in most clinical settings, including cardiovascular disease. However, in daily practice it usually remains unrecognized and consequently untreated. The present review was ideated to answer the main questions about nutritional status assessment in patients with cardiovascular disease: why, when, where, how to evaluate it, and what to do to improve it. The three main cardiovascular diseases, namely aortic stenosis, ischaemic heart disease, and heart failure were considered. First, the main evidence supporting the prognostic role of malnutrition are summarized and analyzed. Second, the main tools for the assessment of malnutrition in the hospital and outpatient setting are reported for each condition. Finally, the possible strategies and interventions to address malnutrition are discussed.
\end{abstract}

Keywords: malnutrition; elderly; aortic stenosis; heart failure; coronary artery disease

\section{Introduction}

Over recent years, the mean age of patients with cardiovascular disease has been significantly increasing. Based on this, cardiologists should become confident with new risk factors characterizing the elderly. Nutritional status is one of them. Nutritional status is a marker of healthy status related to the risk of developing sarcopenia, cachexia, frailty, and disability. Frequently, disorders on nutritional status are associated with worsening of the physical performance and then with the overall condition of the patient. The universe of the nutritional status includes some definitions that must be clarified. Malnutrition is a chronic state characterized by over- and undernutrition and inflammatory status, which changes body composition [1]. Undernutrition is defined as an imbalance in the body's energy intake and requirements. Overnutrition corresponds to an oversupplied intake of nutrients. Elderly patients are more often characterized by undernutrition because of age-related changes in taste, smell, and appetite, and also disease-related inflammation that can contribute to declines in appetite and changes in how the body processes nutrients $[1,2]$.

The nutritional status can be easily investigated by the application of questionnaires, exams and scales. Cardiologists, and in general physicians, challenged with elderly with cardiovascular disease should be confident with malnutrition assessment for two main reasons. First, malnutrition deserves an important prognostic role. Patient's nutritional status and its assessment should be considered part of the risk stratification in elderly. Second, malnutrition should be considered as an actionable risk factor. The presence of malnutrition could guide cardiologists in the implementation of corrective strategies 
potentially associated with a better outcome. These strategies include diet suggestions, nutritional supplements, and physical activity. They have to be individualized according to patient's characteristics and comorbidities in order to plan the best secondary prevention program.

Therefore, the aim of the present review was summarizing evidence, prognostic role, and possible therapeutic strategies between nutritional status in elderly and the most common cardiovascular diseases in order to help cardiologists to perform nutritional evaluation first-hand.

\section{Methods}

A Medline search of full-text articles published in English until November 2020 was performed.

Overall, 3417 records were identified. The search terms were: ((nutritional status) AND ((elderly) OR (older)) AND ((cardiovascular diseases) OR (aortic stenosis) OR (heart failure) OR ((myocardial infarction) OR (MI))). Only papers published in English and in peer-reviewed journals were selected. After evaluation of the title and the abstract, a total of 323 studies were analyzed as full text. The quality of the selected papers was tested using MINORS criteria [3]. Unblinded reviewers performed the analysis of the full texts for quality assessment. Discrepancies between reviewers were solved by consensus. The maximum score obtained was 14 and the minimum was 8 . We included in the present review only studies obtaining a score of 10 . A total of 27 papers were then considered for this overview (Figure 1).

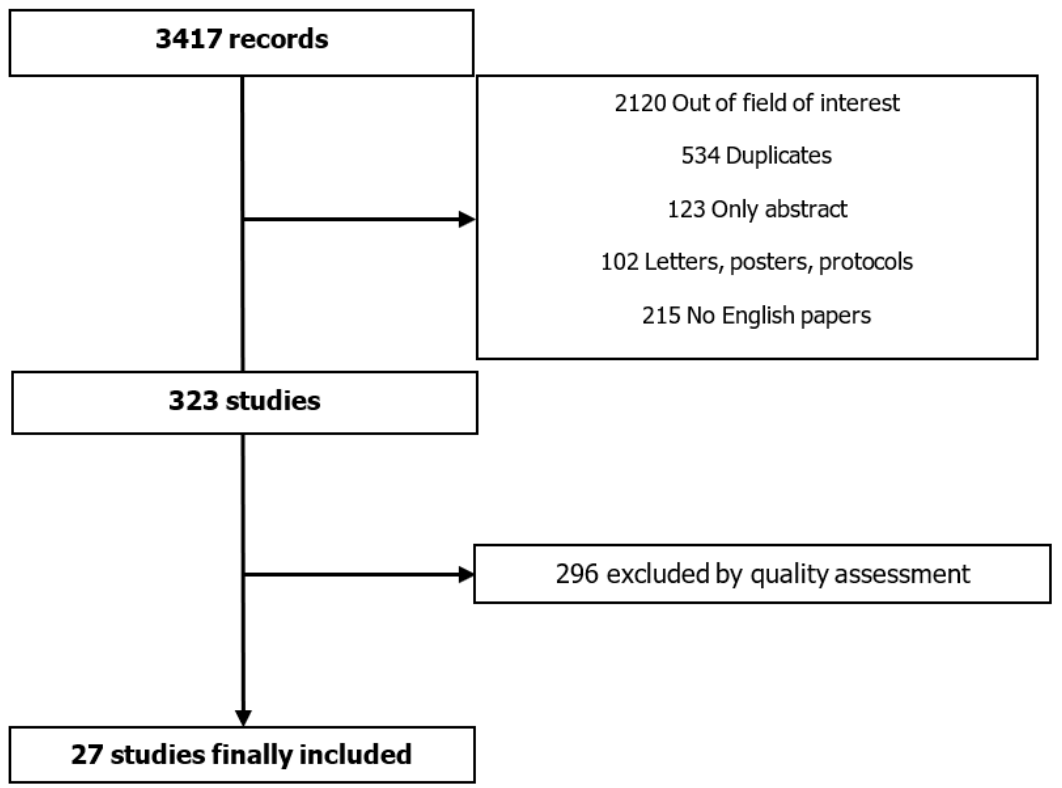

Figure 1. Methodological strategy.

\section{Results}

The following three main cardiovascular diseases were considered: aortic stenosis (AS), coronary artery disease (CAD), and heart failure (HF). The main characteristics of the most important tools used in these settings are summarized in Table 1. 
Table 1. Main scores for the assessment of nutritional status.

\begin{tabular}{|c|c|c|c|}
\hline Score & Brief Description & Cut off Values & Setting of Validation \\
\hline $\begin{array}{c}\text { CONUT [4] } \\
\text { Controlling Nutritional Index }\end{array}$ & $\begin{array}{c}\text { Assess the risk of malnutrition giving points for } \\
\text { each parameter, then summarize the point: } \\
\text { Albumin, } \mathrm{g} / \mathrm{dL} \\
\text { Total cholesterol, } \mathrm{mmol} / \mathrm{L} \\
\text { Lymphocyte count, } \times 10^{9} / \mathrm{L}\end{array}$ & $\begin{array}{c}0-1=\text { no risk } \\
2-4=\text { mild risk } \\
5-8=\text { moderate risk } \\
9-12=\text { severe risk }\end{array}$ & $\begin{array}{l}\text { Aortic stenosis } \\
\text { Coronary artery disease } \\
\text { Heart failure }\end{array}$ \\
\hline $\begin{array}{l}\text { GNRI [5] } \\
\text { Geriatric Nutritional Risk Index }\end{array}$ & $\begin{array}{l}\text { Simple screening tool to assess nutritional } \\
\text { status based on serum albumin and body mass } \\
\text { index. GNRI }=14.89 \times \text { serum albumin }[\mathrm{g} / \mathrm{dL}]+ \\
41.7 \times \text { [actual body weight } / \text { ideal body weight] }\end{array}$ & $\begin{array}{l}>104 \text { no risk } \\
98-104 \text { moderate risk } \\
<98 \text { severe risk }\end{array}$ & $\begin{array}{l}\text { Aortic stenosis } \\
\text { Coronary artery disease } \\
\text { Heart failure }\end{array}$ \\
\hline $\begin{array}{c}\text { PNI [5] } \\
\text { Prognostic } \\
\text { Nutritional Index }\end{array}$ & $\begin{array}{l}\text { Assess the risk of malnutrition with the formula: } \\
10 \times \text { serum albumin }(\mathrm{g} / \mathrm{dL})+0.005 \times \text { total } \\
\text { lymphocyte count }\left(\mathrm{mm}^{3}\right)\end{array}$ & $\begin{array}{l}>38 \text { no risk } \\
35-38 \text { moderate risk } \\
<35 \text { severe risk }\end{array}$ & $\begin{array}{l}\text { Aortic stenosis } \\
\text { Coronary artery disease } \\
\text { Heart failure }\end{array}$ \\
\hline $\begin{array}{c}\text { MNA-SF [6] } \\
\text { Mini Nutritional Assessment -Short Form }\end{array}$ & $\begin{array}{l}\text { Able to identify multifactorial causes of nutritional } \\
\text { risk specifically in elderly. } \\
\text { A questionnaire consisting of } 18 \text { components } \\
\text { grouped into four components, which are } \\
\text { anthropometry data, general status, dietary habits, } \\
\text { self-perceived health, and nutrition status }\end{array}$ & $\begin{array}{l}>24 \text { scores }=\text { no risk } \\
17-23.5 \text { scores }=\text { at risk of malnutrition } \\
<17 \text { scores }=\text { malnourished }\end{array}$ & $\begin{array}{l}\text { Aortic stenosis } \\
\text { Coronary artery disease } \\
\text { Heart failure }\end{array}$ \\
\hline $\begin{array}{c}\text { EFT [7] } \\
\text { Essential Frailty Toolset }\end{array}$ & $\begin{array}{l}\text { The EFT is scored } 0 \text { (least frail) to } 5 \text { (most frail) } \\
\text { based on the following four items: preprocedural } \\
\text { anemia; hypoalbuminemia; lower-extremity muscle } \\
\text { weakness, defined as a time of }>15 \mathrm{~s} \text { or inability to } \\
\text { complete five sit-to-stand repetitions without using } \\
\text { arms; and cognitive impairment, defined as a score } \\
\text { of }<24 \text { on the Mini-Mental State }\end{array}$ & $\begin{array}{l}0-2 \text { low risk of frailty } \\
3-5 \text { high risk of frailty }\end{array}$ & Aortic stenosis \\
\hline Combined Objective Nutritional Score [8] & $\begin{array}{c}\text { Assessment the risk of malnutrition giving } 1 \text { point } \\
\text { each for: high CONUT score }(3-12) \text {, low GNRI }(<98) \\
\text { or low PNI }(<45)\end{array}$ & $\begin{array}{c}0=\text { no risk } \\
1-2=\text { moderate risk } \\
3=\text { severe risk }\end{array}$ & Coronary artery disease \\
\hline $\begin{array}{c}\text { SGA [9] } \\
\text { Subjective Global Assessment }\end{array}$ & $\begin{array}{l}\text { A validated tool consisting of clinical history } \\
\text { (weight loss history, dietary intake changes, } \\
\text { gastrointestinal symptoms persisting for more than } \\
2 \text { weeks, and functional capacity) and physical } \\
\text { examination (subcutaneous fat, muscle wasting, } \\
\text { ankle and sacral edema, and ascites }\end{array}$ & $\begin{array}{l}\text { Based on nutrition rating: } \\
\text { SGA A = well-nourished } \\
\text { SGA B = moderate or suspected undernourished } \\
\text { SGA C = severely undernourished }\end{array}$ & Aortic stenosis \\
\hline
\end{tabular}




\subsection{Aortic Stenosis}

\subsubsection{Why Assess Malnutrition}

AS is the most common degenerative valve disease affecting elderly. This chronic, progressive disease is characterized by a prolonged inflammatory process that may contribute to the reduction of mobility and appetite and the loss of muscle mass. These typical features are of paramount importance, representing real risk factors for adverse outcomes in elderly [6]. Specific tools should be used in order to better estimate malnutrition; as a matter of fact, traditional markers of nutritional status, such as body mass index and body weight, demonstrated that they were not reliable indicators of malnutrition $[6,7]$. Data from the literature have reported a high rate of malnutrition in AS patients (about $65 \%$ in adults $>65$ years old) and its association with increased risk of mortality, hospital readmission, and longer length of hospital stay [7]. The predictive value of nutritional assessment would play a fundamental role in the evaluation elderly undergoing surgical aortic valve replacement (SAVR) and transcatheter aortic valve replacement (TAVR). In fact, it could help to choose the best strategy for each patient, and in patients considered for TAVR it could help acknowledge the possibility of futility. Indeed, Emami et al. [10] demonstrated that malnourished patients (defined according to Healthcare Cost and Utilization Project) undergoing TAVR experienced a higher rate of mortality (10.4\% vs. $2.2 \%$, $p<0.001$ ); furthermore, the incidence of functional decline and poor outcomes at one year after was $>50 \%$ in frail elderly. It has been demonstrated that one-year all-cause mortality occurred in the $27.7 \%$ of malnourished patients undergoing aortic valve replacement, in the $16.3 \%$ of patients at risk for malnutrition, and in the $9.7 \%$ of the well-nourished patients $(p<0.001)$ [6]. In addition, it has been shown that malnutrition attenuates the patient's immune response, leading to delayed wound healing after surgery and consequent infective complications [7].

\subsubsection{When, How, and Where to Assess Malnutrition}

In recent years, several studies have investigated and validated different tools to assess malnutrition in patients affected by aortic stenosis (Table 2 shows the main results) [4-9,9-12]. Nutritional assessment of AS should be performed during hospitalization for any reason with the evidence of symptomatic AS or during outpatient cardiological visits. Regardless of the score used, the prognostic value of malnutrition emerges to be of paramount importance. Considering the most important studies about malnutrition in AS, the most appropriate time to carry out a nutritional status evaluation could be:

- At the moment of the first diagnosis of symptomatic AS to obtain a comprehensive assessment of the patient and identify subjects presenting excessive risk for any type of intervention;

- When choosing the best type of replacement (TAVR or SAVR) for each patient in order to perform a better risk stratification;

- After aortic valve replacement, aiming at estimating residual risk. 
Table 2. Main studies about nutritional tools in aortic stenosis.

\begin{tabular}{|c|c|c|c|c|c|}
\hline $\begin{array}{l}\text { Most Important } \\
\text { Studies }\end{array}$ & $\begin{array}{c}\text { Number of } \\
\text { Patients }\end{array}$ & $\begin{array}{l}\text { Nutritional Tool } \\
\text { Used }\end{array}$ & $\begin{array}{l}\text { Mean Age } \\
\text { (Years) }\end{array}$ & Setting & Results \\
\hline $\begin{array}{c}\text { Goldfarb et al. } \\
{[6]}\end{array}$ & 1158 & MNA-SF & $81.3 \pm 6.1$ & Hospital & $\begin{array}{l}\text { Pts with malnutrition have } \\
\text { 3-fold increase in mortality } \\
\text { one year following AVR }\end{array}$ \\
\hline Afilalo et al. [7] & 1020 & EFT & $82(77-86)$ & Hospital & 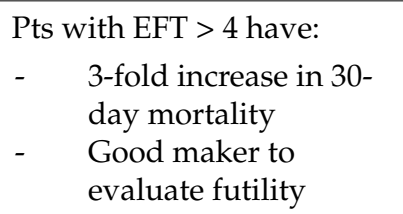 \\
\hline $\begin{array}{l}\text { Honda Y. et al. } \\
\text { [4] }\end{array}$ & 150 & CONUT & $86 \pm 5$ & Hospital & $\begin{array}{l}\text { Association between } \\
\text { CONUT score and increase } \\
\text { mortality after TAVR. }\end{array}$ \\
\hline $\begin{array}{l}\text { Hebeler K. et al. } \\
\text { [11] }\end{array}$ & 470 & $\begin{array}{c}\text { Serum albumin } \\
\text { level }\end{array}$ & $81.7 \pm 7.9$ & Hospital & $\begin{array}{l}\text { Albumin is predictive of } \\
\text { 1-year mortality and may be } \\
\text { a useful variable to include } \\
\text { in TAVR risk scores. }\end{array}$ \\
\hline Lee K et al. [5] & 412 & $\begin{array}{c}\text { GNRI } \\
\text { CONUT }\end{array}$ & $78.7 \pm 5.2$ & Hospital & $\begin{array}{l}\text { GNRI and CONUT score } \\
\text { reflected mortality risk. } \\
\text { Lower GNRI }(\leq 98) \text { was the } \\
\text { only independent predictor } \\
\text { of all-cause death at } 1 \text { year }\end{array}$ \\
\hline $\begin{array}{c}\text { Okuno T et al. } \\
\text { [12] }\end{array}$ & 95 & $\begin{array}{l}\text { GNRI } \\
\text { CONUT } \\
\text { PNI }\end{array}$ & $84(81-88)$ & Hospital & $\begin{array}{l}\text { CONUT score and PNI were } \\
\text { associated with 1-year } \\
\text { clinical outcomes especially } \\
\text { with 1-year all-cause } \\
\text { mortality in patients } \\
\text { undergoing TAVR. } \\
\text { CONUT score and PNI } \\
\text { might have better predictive } \\
\text { values than GNRI }\end{array}$ \\
\hline Wernio et al. [9] & 101 & $\begin{array}{c}\text { f-MNA, 7-SGA, } \\
\text { low } \\
\text { concentrations of } \\
\text { total cholesterol, } \\
\text { LDL-cholesterol, } \\
\text { and prealbumin } \\
\text { were considered }\end{array}$ & $74.6 \pm 5.2$ & Hospital & $\begin{array}{l}\text { In malnourished patients } \\
\text { the risk of postsurgery } \\
\text { complications increased } 1.22 \\
\text { times. } \\
\text { Unintentional weight loss of } \\
>2.8 \% \text { in the six months } \\
\text { preceding surgery predicted } \\
\text { death within the first year } \\
\text { after AVR surgery }\end{array}$ \\
\hline
\end{tabular}

Legend: AVR = aortic valve replacement; CONUT = Controlling Nutritional Status; EFT = Essential Frailty Tool; f-MNA = Low Mini Nutritional Assessment; GNRI = Geriatric Nutritional Risk Index; MNA-SF = Mini Nutritional Assessment Short Form; SAVR = Surgical Aortic Valve Replacement; TAVR = Transcatheter Aortic Valve Replacement; 7-SGA = Subjective Global Assessment.

The necessary elements to be considered to choose the best tool are the patients' age, the co-presence of other unrecognized risk factors such as low physical performance and cognitive impairment, and the settings of patients' assessment, as mentioned earlier. Therefore, for the successful and effective assessment of an AS patient's nutritional status, the tool used should present four fundamental characteristics. It should be easy to perform, include a physical and cognitive function evaluation, have a strong predictive value, and it should not be based on laboratory values only. In view of this, when treating AS patients, the Mini Nutritional Assessment-Short Form (MNA-SF) and the Essential Frailty Tool (EFT) seem to be the best choices as they are easy to perform, not time-consuming, and with a well-established predictive value. 


\subsubsection{Possible Interventions and Ongoing Studies}

Ongoing research aims to investigate feasibility and benefits of nutritional status improvement in AS patients before replacement. Figure 2 shows some diet and lifestyle suggestions, which are just the evidence available up to now [1]. Currently, there are two ongoing trials considering cardiac prehabilitation before aortic valve replacement: the "Prehabilitation to Improve Functional and Clinical Outcomes in Patients With Aortic Stenosis" (TAVR-FRAILTY, NCT02597985) takes into consideration the functional exercise capacity (evaluated with a 6 min walking test) and the "PERFORM-TAVR" trial (PERFORMTAVR, NCT03522454), which is evaluating the effects of a dietary supplement and a homebased supervised exercise program in patients suitable for TAVR.

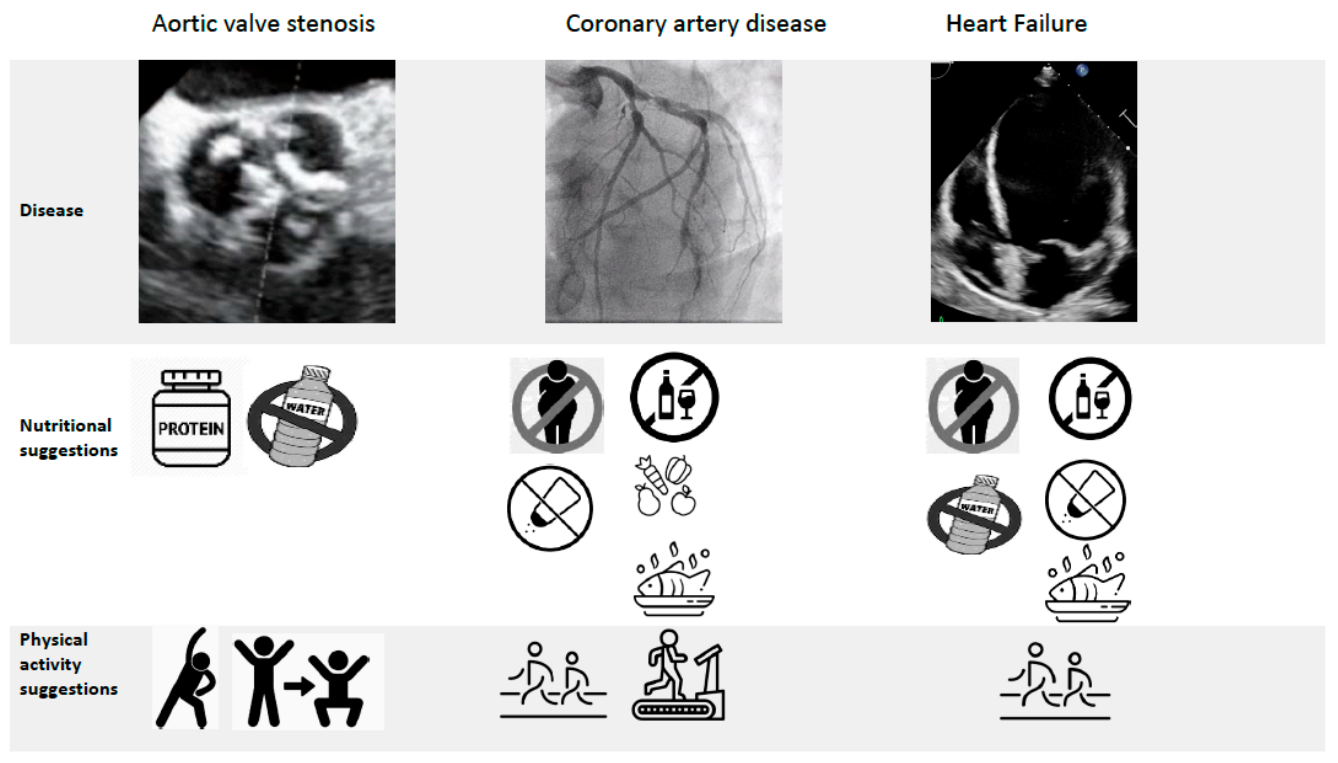

Figure 2. Nutritional and physical activity suggestions currently available in cardiovascular diseases Aortic stenosis: consider protein supplement before and early after surgical aortic valve replacement (SAVR) and transcatheter aortic valve replacement (TAVR), fluid management, ad hoc physical activity in order to improve lean mass. Coronary artery disease: energy intake should be limited to the amount of energy needed to maintain (or obtain) a healthy weight (BMI $<25 \mathrm{~kg} / \mathrm{m}^{2}$ ); $<5 \mathrm{~g}$ of salt per day; 30-45 g of fiber per day from wholegrain products, fruits, and vegetables; fish at least twice a week, one being oily fish; avoid excessive alcohol intake; aerobic physical activity. Heart failure: eat healthy and keep a healthy weight, avoid excessive salt intake ( $<6 \mathrm{~g} /$ day $)$, abstain from or avoid excessive alcohol intake, fluid restriction, an $\omega-3$ polyunsaturated fatty acids preparation may be considered, physical activity.

\subsection{Coronary Artery Disease}

\subsubsection{Why Assess Malnutrition}

CAD is the leading cause of mortality and disability worldwide. The incidence of myocardial infarction (MI) is especially high in the elderly, and it is expected to increase because of the aging of the population [13]. Despite the improvement of strategies, technologies, drugs, and materials, the elderly remains the subgroup of MI patients with the worst prognosis. They show a higher rate of cardiovascular death after MI and 30-day hospital readmission for HF than their younger counterparts [13]. Furthermore, long-term follow-up data showed that two-year occurrence of cardiac death and MI is significantly more frequent in patients aged 75 years and over [14]. These data could be related to several comorbidities and unrecognized, but prognostically significant, risk factors, including malnutrition. Tonet et al. reported that $40 \%$ of patients $>70$ years old admitted for acute coronary syndrome were at risk for malnutrition [15]. Considering stable CAD, Wada et al. [16] reported that $49 \%$ and $24 \%$ of patients were at mild and moderate-severe risk of malnutrition, respectively. Table 3 shows the main studies in the setting of stable 
CAD $[8,16-18]$ and acute MI [15,19-22], evaluating the prognostic value of malnutrition assessed by various tools.

\subsubsection{When, How, and Where to Assess Malnutrition}

As previously reported, two clinical scenarios could require nutritional assessment for better risk stratification of CAD patients:

- Acute setting of MI;

- Outpatient visits of elderly with stable CAD.

During hospital admission, because of MI, the best tool should be easy and fast; MNA$\mathrm{SF}$ and CONUT could represent the best choice, also considering the strong evidence of their prognostic value. For elderly with stable CAD, a more comprehensive tool could be used, such as the PNI or CONS; of note, these scores do not include cholesterol levels, which are influenced by chronic statin therapy in these patients.

\subsubsection{Possible Interventions}

In relation to the strategies for nutritional status improvement, hitherto, there are no validated supplements or programs. As shown in Figure 2, suggestions provided by current guidelines are related to food intake regulation; these indications are useful both in young and older adults with CAD and are only partly aimed at improving lean mass and avoiding malnutrition and sarcopenia. The awareness that nutritional status has a strong prognostic value in elderly patients with CAD could guide secondary prevention programs addressing nutritional strategies' implementation.

\subsection{Heart Failure}

\subsubsection{Why Assess Malnutrition}

Malnutrition is common in patients with chronic HF, with a prevalence of about $45 \%$ [23]. Its association with high mortality is well established. Chronic HF often leads to loss of appetite, malabsorption, and a catabolic state, perpetuating a vicious cycle of malnutrition, cytokine activation, and autonomic dysfunction. The prevalence of malnutrition in chronic HF varies depending on the screening tool used, and it has been reported to be as high as $69 \%$ in some chronic HF populations [24,25]. Regardless of the score used, malnutrition is an independent predictor of worsening HF and mortality. Table 4 shows the main studies about nutritional assessment in HF patients [26-36]. Likewise, malnourished patients hospitalized for acute HF have a three times greater mortality risk than their counterparts with normal nutritional status [23]. During the acute phase of HF, the hepatic congestion and gut edema may cause early satiety and nausea, reducing the food assumption and adsorption. As a consequence, HF patients develop an increasingly poor nutritional status. The association between nutritional status and 30-day mortality among elderly patients with acute HF has also been proven in the emergency department [37]. These findings suggest that the risk of malnutrition should be screened in older patients with acute HF in every context in order to plan the best strategy for each patient. 
Table 3. Main studies about nutritional tools in chronic and acute ischemic heart disease.

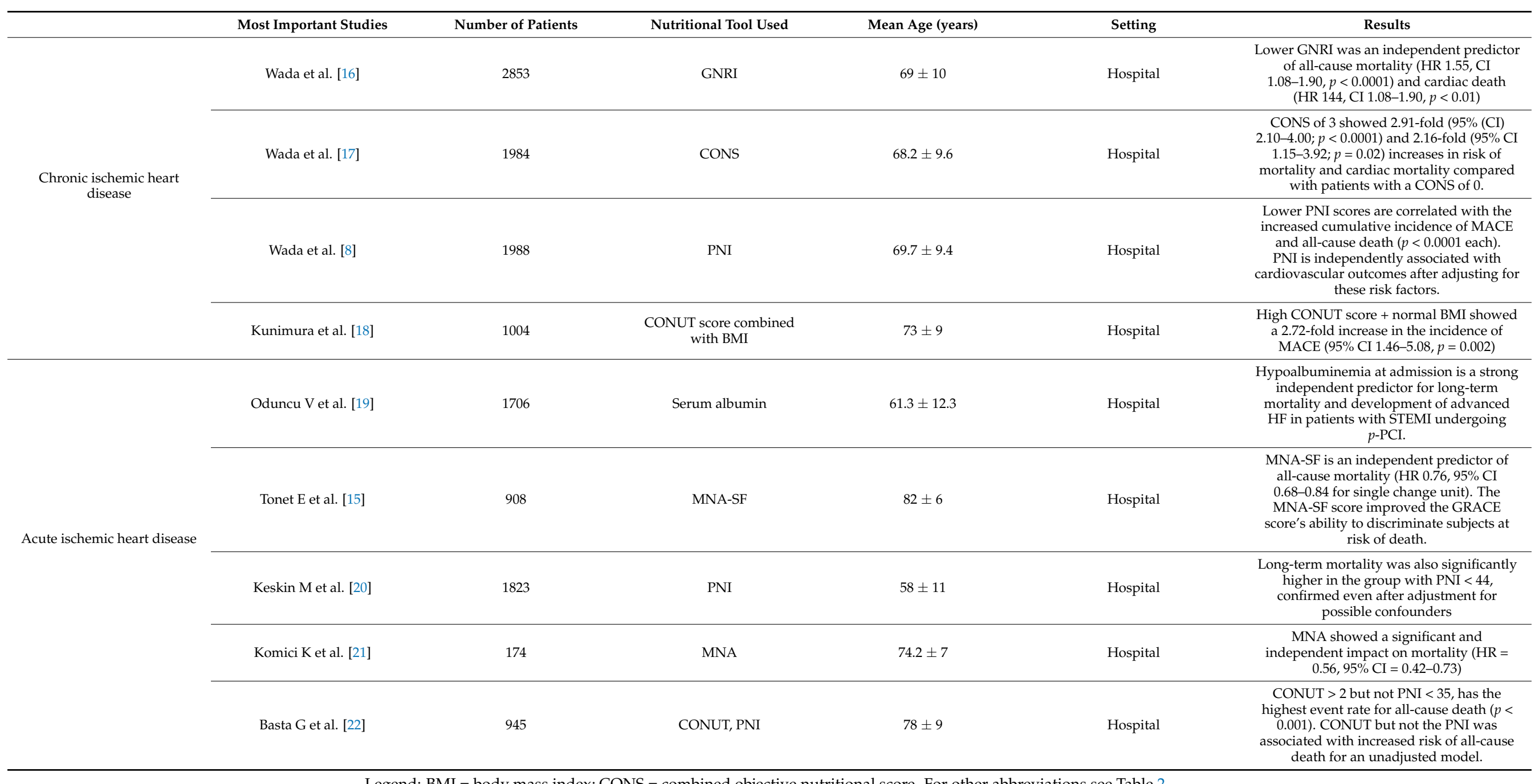

Legend: BMI = body mass index; CONS = combined objective nutritional score. For other abbreviations see Table 2. 
Table 4. Main studies about nutritional tools in heart failure.

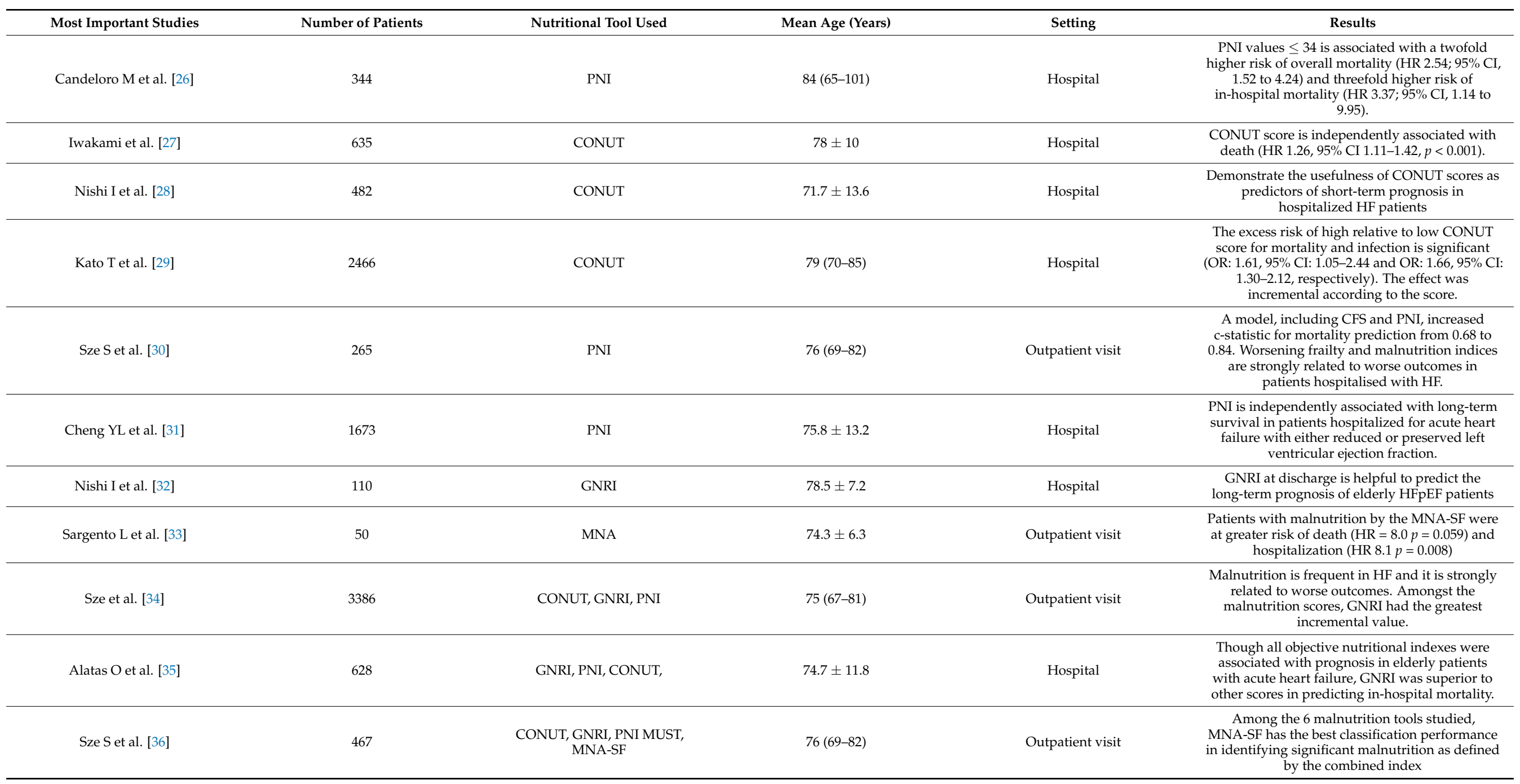

Legend: $\mathrm{HF}=$ heart failure; HFrEF = heart failure with reduced ejection fraction; HFpEF = heart failure with preserved ejection fraction. For other abbreviations see Table 2and Table 3. 


\subsubsection{When, How, and Where to Assess Malnutrition}

The assessment of nutritional status in HF patients should take place in three different scenarios:

- Outpatient visits, as completion of the evaluation of patients with chronic HF;

- Emergency department, in order to identify patients at higher risk for brief-term mortality who could benefit from more intensive care;

- During hospital stay for acute HF with the aim of improving management strategies.

With this background, the best nutritional tool should be easy to perform and comprehensive of laboratory and self-reported data in order to understand the lifestyle of each patients at home. Furthermore, the tool chosen should not consider parameters that could be influenced by ongoing medications, such as cholesterol levels. Considering these features, the best scores in this setting could be PNI, GNRI, and MNA, both in their long and short forms.

\subsubsection{Possible Interventions}

The prognostic importance of malnutrition in HF patients has led to some strategies aimed at improving nutritional status (Figure 2). Dereli et al. [38] demonstrated that switching the anti-remodeling drugs to sacubitril/valsartan significantly improved the nutritional status in patients with HF with reduced ejection fraction. The PICINIC trial is a multicenter, randomized, controlled clinical trial that evaluated an individualized nutritional intervention in malnourished patients (according to MNA) hospitalized for acute HF. The primary endpoint was a composite of all-cause death or readmission for worsening HF, with a maximum follow-up of 12 months. The primary outcome occurred in $27.1 \%$ of patients in the intervention group and $60.7 \%$ of patients in the control group (HR $0.45 ; 95 \%$ CI $0.19-0.62, p=0.0004)$. In total, $20.3 \%$ of patients died in the intervention group and $47.5 \%$ in the control group (HR $0.37,95 \%$ CI, $0.19-0.72, p=0.003$ ). Readmission due to HF was also lower in the intervention group (10.2 vs. $36.1 \%, p=0.001)$. Numbers needed to treat (NNTs) were 2.5 for the composite endpoint and 4 for all-cause mortality. These data show how a nutritional intervention in malnourished hospitalized patients with HF reduces the risk of all-cause death and the risk of readmission for worsening HF [39].

\section{Discussion}

\section{Beyond the Malnutrition Condition}

An important concept emerged from previous studies on the elderly: new risk factors involved in the complexity of these patients include not only malnutrition, but also low physical performance and cognitive decline [40]. While the latter is not frequent in a cardiological setting, malnutrition and low physical performance are often encountered in patients with cardiovascular diseases [41]. These points could be considered two sides of the same coin. As a matter of fact, they are strictly related: on the one hand, poor nutritional status determines a loss of muscle mass with a consequent poor physical performance. On the other hand, low physical performance slows the metabolism and reduces appetite, resulting in lower intake and absorption of nutrients. With this background in mind, nutritional status assessment and improvement are important, but they cannot be considered separated from a physical activity intervention. As previously reported, their impact on prognosis of these patients is of paramount importance. As a matter of fact, the trajectory of elderly patients with cardiovascular diseases and low physical performance and/or malnutrition has been demonstrated to go rapidly down [41]. Additionally, it has to be considered that nutritional status and physical performance reflect the global health status, so that management of these patients should be regulated, also taking into account these characteristics. For example, in the setting of CAD, nutritional status assessment and low physical performance evaluation could guide the invasive strategy, recognizing those patients in which benefits of revascularization could be weakened by pre-frailty and frailty burden [41]. Therefore, the recognition of these risk factors has become fundamental in order to improve management and prognosis of elderly patients. A comprehensive 
assessment of elderly people with cardiac disorders should include both malnutrition and physical performance evaluation. The information should guide tailored intervention of secondary prevention, including diet, nutritional supplements [42], and exercise programs (supervised in well-established facilities or home-based) [43].

\section{Conclusions and Future Directions}

Data incontrovertibly show that the nutritional status is related to poor prognosis in elderly patients affected by cardiovascular diseases, and it is relevant both in the acute and chronic setting. There are several validated context-specific tools to evaluate these patients. The assessment of nutritional status and physical performance should be integrated in the routine clinical practice because it could help choose the best diagnostic and therapeutic pathway for each patient. If, on the one hand, the importance of nutritional status assessment has been widely demonstrated, on the other, there are not enough data showing the benefits of nutritional intervention. How to implement nutritional status of these patients and whether its improvement has a prognostic relevance is still unknown and future studies are clearly on demand.

Author Contributions: E.T. dealt with conception and design, literature analysis, and manuscript writing. R.C. dealt with literature analysis and manuscript writing. S.C. participated in literature analysis. F.G. participated in literature analysis. A.F. participated in literature analysis. G.C. (Giorgio Chiaranda). participated in literature analysis and critical revision of the manuscript for important intellectual content. S.Z. dealt with literature analysis and critical revision of the manuscript for important intellectual content. G.C. (Gianni Casella). dealt with critical revision of the manuscript for important intellectual content. G.C. (Gianluca Campo) dealt with conception and design, manuscript writing, and critical revision of the manuscript for important intellectual content. All authors have read and agreed to the published version of the manuscript.

Funding: This work is partially supported by the grant of the Italian Health Ministry Ricerca Finalizzata 2018 (GR-2018-12367114).

Institutional Review Board Statement: Not applicable.

Informed Consent Statement: Not applicable.

Data Availability Statement: Not applicable.

Conflicts of Interest: The authors declare no conflict of interest.

\section{References}

1. Cruz-Jentoft, A.; Bahat, G.; Bauer, J.; Boirie, Y.; Bruyère, O.; Cederholm, T.; Cooper, C.; Landi, F.; Rolland, Y.; Sayer, A.A.; et al. Sarcopenia: Revised European consensus on definition and diagnosis. Age Ageing 2019, 48, 16-31. [CrossRef]

2. Evans, C. Malnutrition in the Elderly: A Multifactorial Failure to Thrive. Perm. J. 2005, 9, 38-41. [CrossRef] [PubMed]

3. Slim, K.; Nini, E.; Forestier, D.; Kwiatkowski, F.; Panis, Y.; Chipponi, J. Methodological index for non-randomized studies (minors): Development and validation of a new instrument. ANZ J. Surg. 2003, 73, 712-716. [CrossRef] [PubMed]

4. Honda, Y.; Yamawaki, M.; Shigemitsu, S.; Kenji, M.; Tokuda, T.; Tsutumi, M.; Mori, S.; Sakamoto, Y.; Kobayashi, N.; Araki, M.; et al. Prognostic value of objective nutritional status after transcatheter aortic valve replacement. J. Cardiol. 2019, 73, 401-407. [CrossRef]

5. Lee, K.; Ahn, J.M.; Kang, D.Y.; Ko, E.; Kwon, O.; Lee, P.H.; Lee, S.W.; Kim, D.H.; Kim, H.J.; Kim, J.B.; et al. Nutritional status and risk of all-cause mortality in patients undergoing transcatheter aortic valve replacement assessment using the geriatric nutritional risk index and the controlling nutritional status score. Clin. Res. Cardiol. 2020, 109, 161-171. [CrossRef] [PubMed]

6. Goldfarb, M.; Lauck, S.; Webb, J.G.; Asgar, A.W.; Perrault, L.P.; Piazza, N.; Martucci, G.; Lachapelle, K.; Noiseux, N.; Kim, D.H.; et al. Malnutrition and Mortality in Frail and Non-Frail Older Adults Undergoing Aortic Valve Replacement. Circulation 2018, 138, 2202-2211. [CrossRef] [PubMed]

7. Afilalo, J.; Lauck, S.; Kim, D.H.; Lefèvre, T.; Piazza, N.; Lachapelle, K.; Martucci, G.; Lamy, A.; Labinaz, M.; Peterson, M.D.; et al. Frailty in Older Adults Undergoing Aortic Valve Replacement: The FRAILTY-AVR Study. J. Am. Coll. Cardiol. 2017, 70, 689-700. [CrossRef] [PubMed]

8. Wada, H.; Dohi, T.; Miyauchi, K.; Jun, S.; Endo, H.; Doi, S.; Konishi, H.; Naito, R.; Tsuboi, S.; Ogita, M.; et al. Relationship between the prognostic nutritional index and long-term clinical outcomes in patients with stable coronary artery disease. J. Cardiol. 2018, 72, 155-161. [CrossRef] [PubMed] 
9. Wernio, E.; Malgorzewicz, S.; Dardzinska, J.A.; Jagielak, D.; Rogowski, J.; Gruszecka, A.; Klapkowski, A.; Bramlage, P. Association between Nutritional Status and Mortality after Aortic Valve Replacement Procedure in Elderly with Severe Aortic Stenosis. Nutrients 2019, 11, 446. [CrossRef]

10. Emami, S.; Rudasill, S.; Bellamkonda, N.; Sanaiha, Y.; Cale, M.; Madrigal, J.; Christian-Miller, N.; Benharash, P. Impact of Malnutrition on Outcomes Following Transcatheter Aortic Valve Implantation (from a National Cohort). Am. J. Cardiol. 2020, 125, 1096-1101. [CrossRef]

11. Hebeler, K.R.; Baumgarten, H.; Squiers, J.J.; Wooley, J.; Pollock, B.D.; Mahoney, C.; Filardo, G.; Lima, B.; DiMaio, J.M. Albumin Is Predictive of 1-Year Mortality After Transcatheter Aortic Valve Replacement. Ann. Thorac. Surg. 2018, 106, 1302-1307. [CrossRef] [PubMed]

12. Okuno, T.; Koseki, K.; Nakanishi, T.; Sato, K.; Ninomiya, K.; Tomii, D.; Tanaka, T.; Sato, Y.; Horiuchi, Y.; Koike, H.; et al. Evaluation of objective nutritional indexes as predictors of one-year outcomes after transcatheter aortic valve implantation. J. Cardiol. 2019, 74, 34-39. [CrossRef]

13. Madhavan, M.V.; Gersh, B.J.; Alexander, K.P.; Granger, C.B.; Stone, G.W. Coronary Artery Disease in Patients $>/=80$ Years of Age. J. Am. Coll. Cardiol 2018, 71, 2015-2040. [CrossRef]

14. Qin, Y.; Wie, X.; Han, H.; Wen, Y.; Gu, K.; Ruan, Y.; Lucas, C.H.; Baber, U.; Tomey, M.I.; He, J. Association between age and readmission after percutaneous coronary intervention for acute myocardial infarction. Heart 2020, 106, 1595-1603. [CrossRef] [PubMed]

15. Tonet, E.; Campo, G.; Maietti, E.; Formiga, F.; Martinez-Sellés, M.; Pavasini, R.; Biscaglia, S.; Serenelli, M.; Sanchis, J.; DiezVillanueva, P.; et al. Nutritional status and all-cause mortality in older adults with acute coronary syndrome. Clin. Nutr. 2020, 39, 1572-1579. [CrossRef]

16. Wada, H.; Dohi, T.; Miyauchi, K.; Doi, S.; Naito, R.; Konishi, H.; Tsuboi, S.; Ogita, M.; Kasai, T.; Hassan, A.; et al. Prognostic Impact of the Geriatric Nutritional Risk Index on Long-Term Outcomes in Patients Who Underwent Percutaneous Coronary Intervention. Am. J. Cardiol. 2017, 119, 1740-1745. [CrossRef] [PubMed]

17. Wada, H.; Dohi, T.; Miyauchi, K.; Doi, S.; Konishi, H.; Naito, R.; Tsuboi, S.; Ogita, M.; Kasai, T.; Okazaki, S.; et al. Prognostic impact of nutritional status assessed by the Controlling Nutritional Status score in patients with stable coronary artery disease undergoing percutaneous coronary intervention. Clin. Res. Cardiol. 2017, 106, 875-883. [CrossRef] [PubMed]

18. Kunimura, A.; Ishii, H.; Uetani, T.; Aoki, T.; Harada, K.; Hirayama, K.; Negishi, Y.; Shibita, Y.; Sumi, T.; Kawashima, K.; et al. Impact of nutritional assessment and body mass index on cardiovascular outcomes in patients with stable coronary artery disease. Int. J. Cardiol. 2017, 230, 653-658. [CrossRef]

19. Oduncu, V.; Erkol, A.; Karabay, C.Y.; Kurt, M.; Akgun, T.; Bulut, M.; Pala, S.; Kirma, C. The prognostic value of serum albumin levels on admission in patients with acute ST-segment elevation myocardial infarction undergoing a primary percutaneous coronary intervention. Coron. Artery. Dis. 2013, 24, 88-94. [CrossRef] [PubMed]

20. Keskin, M.; Hayıroğlu, M.İ.; Keskin, T.; Kaya, A.; Tatlisu, M.A.; Altay, S.; Uzon, A.O.; Borklu, E.B.; Guvenc, T.S.; Avci, I.I.; et al. A novel and useful predictive indicator of prognosis in ST-segment elevation myocardial infarction; prognostic nutritional index. Nutr. Metab. Cardiovasc. Dis. 2017, 27, 438-446. [CrossRef]

21. Komici, K.; Vitale, D.F.; Mancini, A.; Bencivegna, L.; Conte, M.; Provenzano, S.; Grieco, F.V.; Visaggi, L.; Ronga, I.; Cittadini, A.; et al. Impact of Malnutrition on Long-Term Mortality in Elderly Patients with Acute Myocardial Infarction. Nutrients 2019, 11, 224. [CrossRef] [PubMed]

22. Basta, G.; Chatzianagnostou, K.; Paradossi, U.; Botto, N.; Del Turco, S.; Taddei, A.; Berti, S.; Mazzone, A. The prognostic impact of objective nutritional indices in elderly patients with ST-elevation myocardial infarction undergoing primary coronary intervention. Int. J. Cardiol. 2016, 221, 987-992. [CrossRef]

23. Aziz, E.F.; Javed, F.; Pratap, B.; Musat, D.; Nader, A.; Pulimi, S.; Alivar, C.L.; Herzog, E.; Kukin, M.L. Malnutrition as assessed by nutritional risk index is associated with worse outcome in patients admitted with acute decompensated heart failure: An ACAP-HF data analysis. Heart Int. 2011, 6, e2. [CrossRef]

24. Lin, H.; Zhang, H.; Lin, Z.; Li, X.; Kong, X.; Sun, G. Review of nutritional screening and assessment tools and clinical outcomes in heart failure. Heart Fail. Rev. 2016, 21, 549-565. [CrossRef]

25. Sze, S.; Pellicori, P.; Zhang, J.; Weston, J.; Clark, A.L. Agreement and Classification Performance of Malnutrition Tools in Patients with Chronic Heart Failure. Curr. Dev. Nutr. 2020, 4, nzaa071. [CrossRef] [PubMed]

26. Candeloro, M.; Di Nisio, M.; Balducci, M.; Genova, S.; Valeriani, E.; Pierdomenico, S.D.; Porreca, E. Prognostic nutritional index in elderly patients hospitalized for acute heart failure. ESC Heart Fail. 2020, 7, 2479-2484. [CrossRef]

27. Iwakami, N.; Nagai, T.; Furukawa, T.A.; Sugano, Y.; Honda, S.; Okada, A.; Asaumi, Y.; Aiba, T.; Noguchi, T.; Kusano, K.; et al. Prognostic value of malnutrition assessed by Controlling Nutritional Status score for long-term mortality in patients with acute heart failure. Int. J. Cardiol. 2017, 230, 529-536. [CrossRef] [PubMed]

28. Nishi, I.; Seo, Y.; Hamada-Harimura, Y.; Sato, K.; Sai, S.; Yamamoto, M.; Ishizu, T.; Sugano, A.; Obara, K.; Wu, L.; et al. Cardiovascular Assessment Study-Heart Failure Investigators. Utility of Nutritional Screening in Predicting Short-Term Prognosis of Heart Failure Patients. Int. Heart J. 2018, 59, 354-360. [CrossRef] [PubMed]

29. Kato, T.; Yaku, H.; Morimoto, T.; Inuzuka, Y.; Tamaki, Y.; Yamamoto, E.; Yoshikawa, Y.; Kitai, T.; Taniguchi, R.; Iguchi, M.; et al. Association with Controlling Nutritional Status (CONUT) Score and In-hospital Mortality and Infection in Acute Heart Failure. Sci. Rep. 2020, 10, 3320. [CrossRef] [PubMed] 
30. Sze, S.; Zhang, J.; Pellicori, P.; Morgan, D.; Hoye, A.; Clark, A.L. Prognostic value of simple frailty and malnutrition screening tools in patients with acute heart failure due to left ventricular systolic dysfunction. Clin. Res. Cardiol. 2017, 106, 533-541. [CrossRef]

31. Cheng, Y.L.; Sung, S.H.; Cheng, H.M.; Hsu, P.F.; Guo, C.Y.; Yu, W.C.; Chen, C.H. Prognostic Nutritional Index and the Risk of Mortality in Patients With Acute Heart Failure. J. Am. Heart Assoc. 2017, 6, e004876. [CrossRef] [PubMed]

32. Nishi, I.; Seo, Y.; Hamada-Harimura, Y.; Yamamoto, M.; Ishizu, T.; Sugani, A.; Sato, K.; Sai, S.; Obara, K.; Suzuki, S.; et al. Cardiovascular Assessment Study-Heart Failure Investigators. Geriatric nutritional risk index predicts all-cause deaths in heart failure with preserved ejection fraction. ESC Heart Fail. 2019, 6, 396-405. [CrossRef] [PubMed]

33. Sargento, L.; Satendra, M.; Almeida, I.; Sousa, A.C.; Gomes, S.; Salazar, F.; Lousada, N.; Dos Reis, R.P. Nutritional status of geriatric outpatients with systolic heart failure and its prognostic value regarding death or hospitalization, biomarkers and quality of life. J. Nutr. Health Aging 2013, 17, 300-304. [CrossRef] [PubMed]

34. Sze, S.; Zhang, J.; Pellicori, P.; Kazmi, S.; Rigby, A.; Cleland, J.G.F.; Wong, K.; Clark, A.L. Prevalence and Prognostic Significance of Malnutrition Using 3 Scoring Systems Among Outpatients With Heart Failure, A Comparison with Body Mass Index. J. Am. Coll. Cardiol. Heart Fail 2018, 6, 476-486.

35. Alataş, Ö.D.; Biteker, M.; Yildirim, B.; Acar, E.; Gokcek, K. Comparison of objective nutritional indexes for the prediction of in-hospital mortality among elderly patients with acute heart failure. Eur. J. Emerg. Med. 2020, 27, 362-367. [CrossRef] [PubMed]

36. Sze, S.; Pellicori, P.; Zhang, J.; Weston, J.; Clark, A.L. The impact of malnutrition on short-term morbidity and mortality in ambulatory patients with heart failure. J. Clin. Nutr. 2021, 113, 695-705. [CrossRef]

37. Martín-Sánchez, F.J.; Triana, F.C.; Rossello, X.; Garcia, R.P.; Garcia, G.L.; Caimari, F.; Vidan, M.T.; Artacho, P.R.; Del Castillo, J.G.; Llorens, P.; et al. Effect of risk of malnutrition on 30-day mortality among older patients with acute heart failure in Emergency Departments. Eur. J. Intern. Med. 2019, 65, 69-77. [CrossRef]

38. Dereli, S.; Bayramoğlu, A.; Kaya, A. Effects of sacubutril/valsartan on nutritional status in heart failure with reduced ejection fraction. J. Cardiovasc. Med. 2020, 21, 13-20. [CrossRef]

39. Bonilla-Palomas, J.L.; Gámez-López, A.L.; Castillo-Domínguez, J.C.; Moreno-Conde, M.; Lopez Ibanez, M.C.; Exposito, R.A.; Ortega, E.R.; Anguita-Sanchez, M.; Villar-Raez, A. Nutritional Intervention in Malnourished Hospitalized Patients with Heart Failure. Arch. Med. Res. 2016, 47, 535-540. [CrossRef]

40. Campo, G.; Maietti, E.; Tonet, E.; Biscaglia, S.; Ariza-Solé, A.; Pavasini, R.; Tebaldi, M.; Cimaglia, P.; Bugani, G.; Serenelli, M.; et al. The Assessment of Scales of Frailty and Physical Performance Improves Prediction of Major Adverse Cariac Events in Older Adults with Acute Coronary Syndrome. J. Gerontol. A Biol. Sci. Med. Sci. 2020, 75, 1113-1119. [CrossRef]

41. Tonet, E.; Pavasini, R.; Biscaglia, S.; Campo, G. Frailty in patients admitted to hospital for acute coronary syndrome: When, how and why? J. Geriatric. Cardiol. 2019, 16, 129-137.

42. Campo, G.; Tonet, E.; Chiaranda, G.; Sella, G.; Maietti, E.; Mazzoni, G.; Biscaglia, S.; Pavasini, R.; Myers, J.; Grazzi, G. Exercise Intervention to Improve Functional Capacity in Older Adults After Acute Coronary Syndrome. J. Am. Coll. Cardiol. 2019, 74, 2948-2950. [CrossRef] [PubMed]

43. Campo, G.; Tonet, E.; Chiaranda, G.; Sella, G.; Maietti, E.; Bugani, G.; Vitali, F.; Serenelli, M.; Mazzoni, G.; Ruggiero, R.; et al. Exercise intervention improves quality of life in older adults after myocardial infarction: Randomized clinical trial. Heart 2020, 106, 1658-1664. [CrossRef] [PubMed] 